\title{
Impacts of the North Atlantic gyre circulation on Holocene climate off northwest Africa
}

\author{
Jung-Hyun $\mathrm{Kim}^{*+}$ \\ Helge Meggers* - Universität Bremen, FB 5 Geowissenschaften, Klagenfurter Straße, D-28359 Bremen, Germany \\ Norel Rimbu* \\ Gerrit Lohmann* - Alfred Wegener Institute for Polar and Marine Research, Bussestrasse 24, D-27570 Bremerhaven, Germany \\ Tim Freudenthal ${ }^{*}$ \\ Peter J. Müller* - Universität Bremen, FB 5 Geowissenschaften, Klagenfurter Straße, D-28359 Bremen, Germany \\ Ralph R. Schneider* Christian-Albrechts-Universität zu Kiel, Institut für Geowissenschaften, Ludewig-Meyn-Strasse 10, \\ D-24118 Kiel, Germany
}

\section{ABSTRACT}

We present well-dated high-resolution Holocene records of seasurface temperature (SST) and upwelling intensity off northwest (NW) Africa. We identify long-term cooling trends over the Holocene in the subtropical North Atlantic in response to boreal summer insolation. A pronounced cooling event of $\sim{ }^{\circ} \mathrm{C}$ ca. $8.5 \mathrm{cal} \mathrm{ka}$ indicates a large-scale reorganization of the ocean current system possibly induced by meltwater from the northern North Atlantic. Our alkenone SST record off Cape Ghir provides strong evidence for the impact of ocean circulation changes on subtropical North Atlantic SSTs. It is likely that cold waters were propagated to the subtropics via the Canary Current in a way similar to Heinrich events and the Younger Dryas off Cape Blanc. We find 2-3 k.y. periodic variations in SST and upwelling intensity off NW Africa superimposed on the cooling trend. Such a cycle has been documented in various paleoclimate archives in phase with solar forcing. We show that these variations on millennial time scales are linked to the North Atlantic subtropical gyre circulation and the Northern Hemisphere atmospheric circulation, and in particular to changes in the pressure gradient between the Icelandic Low and the Azores High. This suggests that oceanic circulation, in response to solar forcing, played a more important role in the generation of 2-3 k.y. cyclicity than has been previously considered.

Keywords: alkenone sea-surface temperature, Holocene, North Atlantic subtropical gyre circulation, upwelling intensity, trade winds.

\section{INTRODUCTION}

Although the Holocene has been regarded as a relatively stable climatic period when compared to the last glacial and viewed in a longterm perspective, paleoclimate records provide growing evidence of an unstable Holocene climate mode in the North Atlantic realm (e.g., Bond et al., 2001; Mayewski et al., 2004). Well-dated paleoclimate records are unique tools for detecting natural Holocene climate variations beyond the instrumental period and to validate climate models that provide past climate scenarios and climate forecasts. However, there is a lack of high-resolution Holocene climate records for the middle to low latitudes, especially in the North Atlantic subtropical gyre and in eastern boundary current systems.

Here we present high-resolution paleoclimate records obtained from marine sediment core GeoB 6007-2 recovered from coastal northwest (NW) Africa $\left(30^{\circ} 51.0^{\prime} \mathrm{N}, 10^{\circ} 16.1^{\prime} \mathrm{W}, 582 \mathrm{~m}\right.$ water depth; Fig. 1). In this region, the eastern branch of the North Atlantic subtropical gyre circulation is maintained by the southwestward flowing Canary Current along the

*E-mails: jhkim@nioz.nl; meggers@uni-bremen.de; nrimbu@awi.de; lohmann@awi.de; freuden@marum.de; pmueller@allgeo.uni-bremen.de; schneider@gpi.uni-kiel.de.

Current address: Royal Netherlands Institute for Sea Research, Department of Marine Biogeochemistry and Toxicology, PO Box 59, 1790 AB Den Burg, Texel, Netherlands.

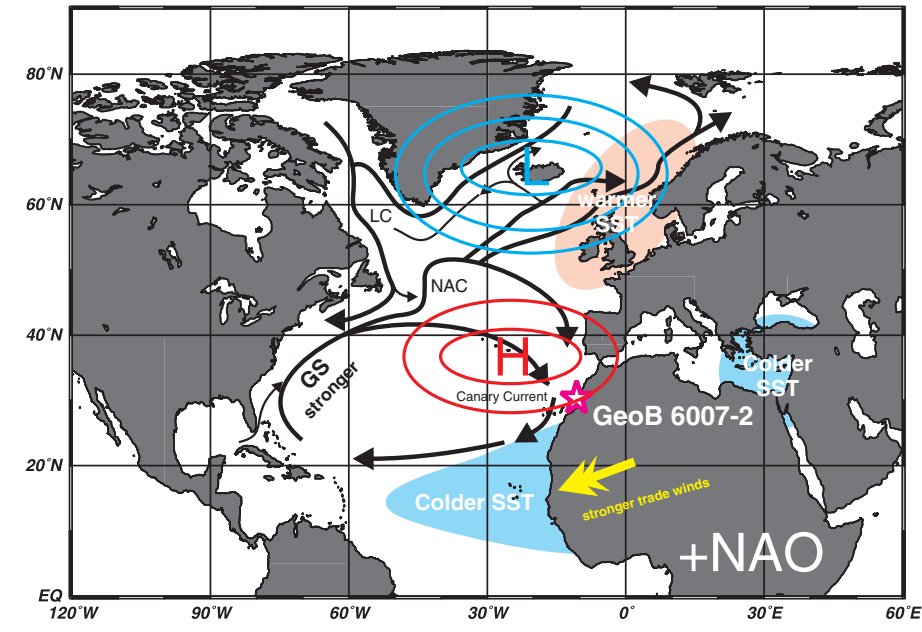

Figure 1. North Atlantic surface ocean circulation (black lines, modified from Meincke, 2002), location of Iceland Low (L) and Azores High (H), dominant Northeast trade winds (yellow arrows), and seasurface temperature (SST) distribution pattern (blue and pink shading) during positive North Atlantic Oscillation (NAO) phase. GS-Gulf Stream, NAC-North Atlantic Current, LC—Labrador Current. Purple star represents location of GeoB 6007-2.

edge of NW Africa (Stramma and Siedler, 1988). The wind-driven coastal upwelling of cool and nutrient-rich subsurface water is strongly coupled with the northeast (NE) trade winds.

\section{METHODS AND DATA}

We applied the alkenone paleothermometry to estimate sea-surface temperatures (SSTs) and the alkenone concentration for phytoplankton productivity (e.g., Müller et al., 1998; Lawrence et al., 2006). Alkenone SST records off NW Africa represent principally the yearly average of the mixed-layer temperature (Müller and Fischer, 2001). At our sediment core location Globigerina bulloides proliferates in highest numbers during summer and fall, when upwelling is strongest due to enhanced NE trade winds (Abrantes et al., 2002). During stronger upwelling periods, higher G. bulloides abundances should correspond to heavier $\delta^{18} \mathrm{O}_{\text {G. bulloides }}$ values, because the advection of cold, nutrient-rich deeper waters to shallow level results in higher $\delta^{18} \mathrm{O}$ values of planktic foraminifera (e.g., Kroon and Darling, 1995). Therefore, we use the $\delta^{18} \mathrm{O}_{G \text {. bulloides }}$ as an isotopic indicator for changes in upwelling intensity off NW Africa.

In order to identify coherent regional SST variations, we compared the alkenone SST record from GeoB 6007-2 to other alkenone SST data from the North Atlantic, Mediterranean Sea, and Red Sea regions. We applied empirical orthogonal function (EOF) and singular spectrum analysis (SSA) to assess temporal and spatial distribution patterns and to identify millennialscale temporal variations in the paleoclimate records. We also examine the 
link between SST and ocean circulation using instrumental data and model simulations. (Further information on methods and data is available as supplementary materials in the GSA Data Repository ${ }^{1}$.)

\section{RESULTS AND DISCUSSION}

The most pronounced feature of the alkenone SST record from GeoB $6007-2$ is a gradual cooling of $\sim 2{ }^{\circ} \mathrm{C}$ from $10 \mathrm{cal}$ ka to present (Fig. 2A). A remarkably abrupt cooling of $\sim 1.0^{\circ} \mathrm{C} \mathrm{ca}$. $8.5 \mathrm{cal} \mathrm{ka}$ and millennial-scale variations of $0.5^{\circ} \mathrm{C}$ are superimposed on the long-term trend. In contrast, the alkenone concentration (Fig. 2B) and $\delta^{18} \mathrm{O}_{G \text {. bulloides }}$ (Fig. 2C) records do not show a clear long-term trend, but higher variability on centennial to millennial time scales.

Compared to a distinct and pronounced minimum in $\delta^{18} \mathrm{O}_{\text {ice }}$, the $8.2 \mathrm{ka}$ event (Fig. 2D; see Rohling and Pälike, 2005, for a review), the abrupt cooling event recorded off NW Africa started earlier and lasted longer. However, such a sharp and strong cooling event was not repeated off NW Africa in the following Holocene. Considering such distinctiveness of cooling and the age model uncertainties due to unknown regional reservoir effect, we regard the cooling ca. $8.5 \mathrm{cal}$ ka off NW Africa as the $8.2 \mathrm{ka}$ event. The $8.2 \mathrm{ka}$ event is widely documented around the North Atlantic region (e.g., von Grafenstein et al., 1998). It is assumed that the 8.2 ka event, the most abrupt and widespread cold event in the past $10 \mathrm{k} . \mathrm{y}$., was caused by a sudden increase in freshwater flux associated with the final deglaciation stages of the Laurentide ice sheet (Barber et al., 1999; Renssen et al., 2001). It is likely that a massive freshwater influx slowed down the thermohaline circulation (THC) and the associated climate signal was propagated to the subtropics via the Canary Current in a way similar to Heinrich events and the Younger Dryas off Cape Blanc (Zhao et al., 1995). According to a freshwater modeling study for Holocene conditions (Lohmann, 2003; Prange et al., 2004), the site GeoB 6007-2 seems to be a proper location to detect the temperature response of THC slowdown induced by high-latitude freshening (Fig. DR1; see footnote 1). The numerical experiments suggest that an intensification of the Canary Current is associated with anomalous advection of cold water from the north.

For the Holocene, the first $\mathrm{EOF}_{\text {alkenone }}$ of the alkenone SST records (Figs. 3A, 3B), representing $62 \%$ of the total variance of alkenone SST, and its associated time coefficient $\left(\mathrm{PC}_{\text {alkenone }}\right.$, Fig. $\left.3 \mathrm{C}\right)$ show a long-term cooling in the eastern North Atlantic and the western Mediterranean Sea, and a warming in the northern Red Sea and the western North Atlantic. The overall long-term cooling in the North Atlantic can be explained by the decreasing boreal summer insolation throughout the Holocene (Fig. 3D; Berger and Loutre, 1991), supporting work by Marchal et al. (2002) and Lorenz et al. (2006). In addition to the direct insolation influence, there is a trend toward a weaker Icelandic Low (Rimbu et al., 2003) associated with high-latitude sea ice responses (Lohmann et al., 2005).

The reconstructed signals from the SSA components of the $\mathrm{PC} 1_{\text {alkenone }}$ $\left(\mathrm{PC}_{\text {alkenone }}:\right.$ SSA34, Fig. 4A), and the GeoB 6007-2 alkenone SST, alkenone concentration, and $\delta^{18} \mathrm{O}_{\text {G. bulloides }}$ records (SST:SSA12, K'37:SSA34, and $\delta^{18} \mathrm{O}: S S A 12$, Figs. 4B-4D), show millennial-scale variability with a 2-3 k.y. periodicity. The North Atlantic Deep Water (NADW) production record from Ocean Drilling Program (ODP) Site 980 (NADW:SSA12, Oppo et al., 2003) also shows the 2-3 k.y. cycle (Fig. 4E), contemporaneous with the $\mathrm{PC} 1_{\text {alkenone }}$ and the $\mathrm{GeoB} 6007-2$ paleoclimate records, within the age uncertainties. Such a 2-3 k.y. cycle has been documented in various paleoclimate archives (Mayewski et al., 2004).

Our study supports the hypothesis that solar activity is involved in the 2-3 k.y. cycle during the Holocene (Rohling et al., 2002; Mayewski et al.,

${ }^{1}$ GSA Data Repository item 2007094, Figure DR1 (temperature, salinity, and horizontal velocity characteristics after a meltwater perturbation), Table DR1 (radiocarbon age data) and Table DR2 (core locations and supplemental information for each SST record), is available online at www.geosociety.org/pubs/ft2007. htm, or on request from editing@geosociety.org or Documents Secretary, GSA, P.O. Box 9140, Boulder, CO 80301, USA.

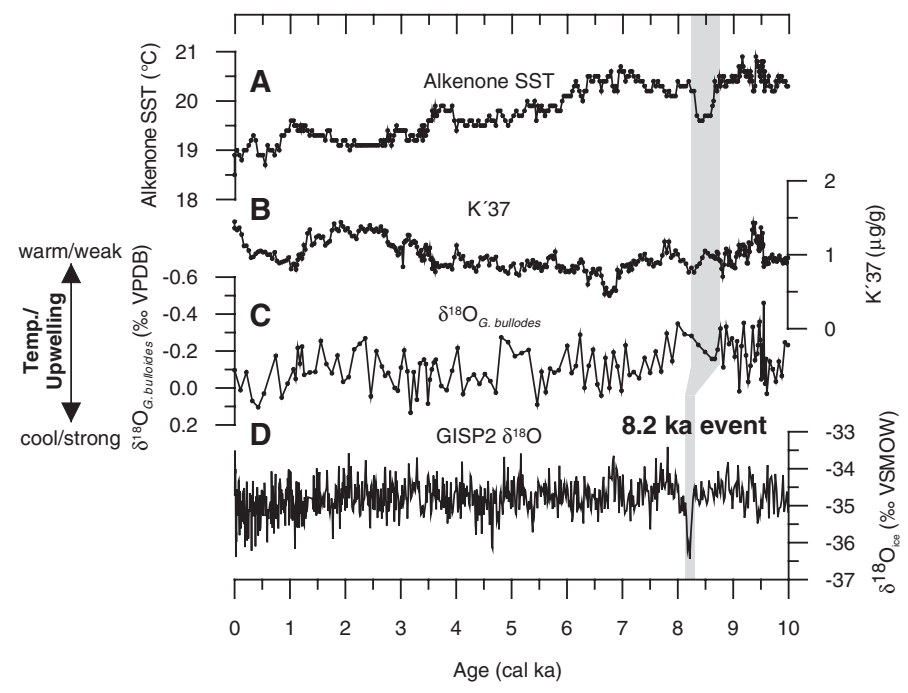

Figure 2. Records from GeoB 6007-2. A: Alkenone sea-surface temperature (SST). B: Alkenone concentration (K'37, sum of $C_{37: 3}$ and $C_{37: 2}$ alkenones). $\mathrm{C}: \delta^{18} \mathrm{O}_{\text {G. bulloides }}$. Solid triangles mark ${ }^{14} \mathrm{C}$ age control points for GeoB 6007-2. D: $\delta^{18} \mathrm{O}_{\text {ice }}$ record from Greenland Ice Sheet Project 2 (GISP2; Stuiver and Grootes, 2000). Vertical gray bar shows inferred timing of 8.2 ka event in GeoB 6007-2 and GISP2 records. VSMOWVienna standard mean ocean water. VPDB-Vienna Peedee belemnite.

2004). The signature of solar variations during the Holocene is consistent with the spatial pattern as obtained from instrumental data covering the past $150 \mathrm{yr}$ (Lohmann et al., 2004; Dima et al., 2005). This is inferred from the similarity of the anti-phase SST signal between the northeastern North Atlantic and the northern Red Sea (Fig. 3B). Our results of the EOF analysis reinforce the findings of Rimbu et al. (2004), who argued that during the Holocene, the Arctic Oscillation-North Atlantic Oscillation (AO-NAO)-like atmospheric circulation was the dominant climate mode at millennial time scales. However, the positive AO-NAO-like phases in the $\mathrm{PC}_{\text {alkenone }}$ (Fig. 4A) correlate with the warmer periods of alkenone SST record off NW Africa (Fig. 4B), not showing the expected cooling for this region during a positive AO-NAO phase (Fig. 1). This implies that other mechanisms were involved in the 2-3 k.y. cycle of alkenone SST in the NW Africa upwelling region. The alkeneone concentrations (Fig. 4C) are higher during the cold periods, indicating that SST and productivity are positively coupled on $2-3 \mathrm{k} . \mathrm{y}$. cycles but negatively with the AO-NAO-like phases. In contrast, the reconstructed SSA signal of the $\delta^{18} \mathrm{O}_{G \text {. bulloides }}$ record shows increased upwelling intensity off NW Africa (heavier $\delta^{18} \mathrm{O}_{\text {G. bulloides }}$ values, Fig. 4D) during positive AO-NAO phases (Fig. 4A). The increased NADW production periods (Fig. 4E) are also coupled to the positive AO-NAO-like phases (Fig. 4A). This is similar to observations from the instrumental period, which shows that during the positive AO-NAO phases the North Atlantic circulation is strengthened, causing increases in the oceanic heat transport by the Gulf Stream-North Atlantic Current from the subtropics to the northern North Atlantic (Curry and McCartney, 2001). In this picture SST anomalies are propagated along the gyre circulation pathways (cf. Sutton and Allen, 1997).

In order to demonstrate the relation of the SST off NW Africa to the Gulf Stream, we performed a correlation and regression analysis between the strength of the Florida Current and SST for the period 1982-2005. A significant relationship is found for values above and below $\pm 0.02{ }^{\circ} \mathrm{C} / \mathrm{Sv}$ when applying a Student's t-test (not shown). Figure 5 reveals the significant relation of SSTs off NW Africa with the Florida Current. From the analogy with the instrumental record, we argue that during the Holocene positive phases the North Atlantic subtropical gyre circulation was strengthened and warmer surface water was transported to the NW Africa upwelling region. Therefore we assume that warming recorded in alkenone SST off NW Africa during the 

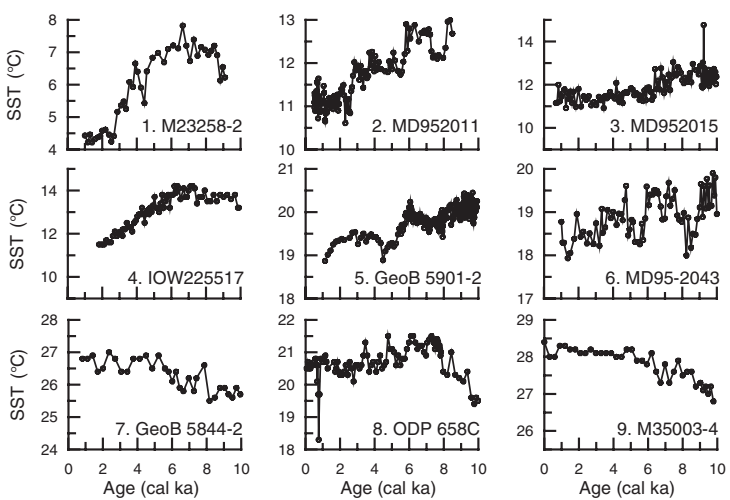

$\mathrm{EOF}_{\text {alkenone }}(62 \%)$
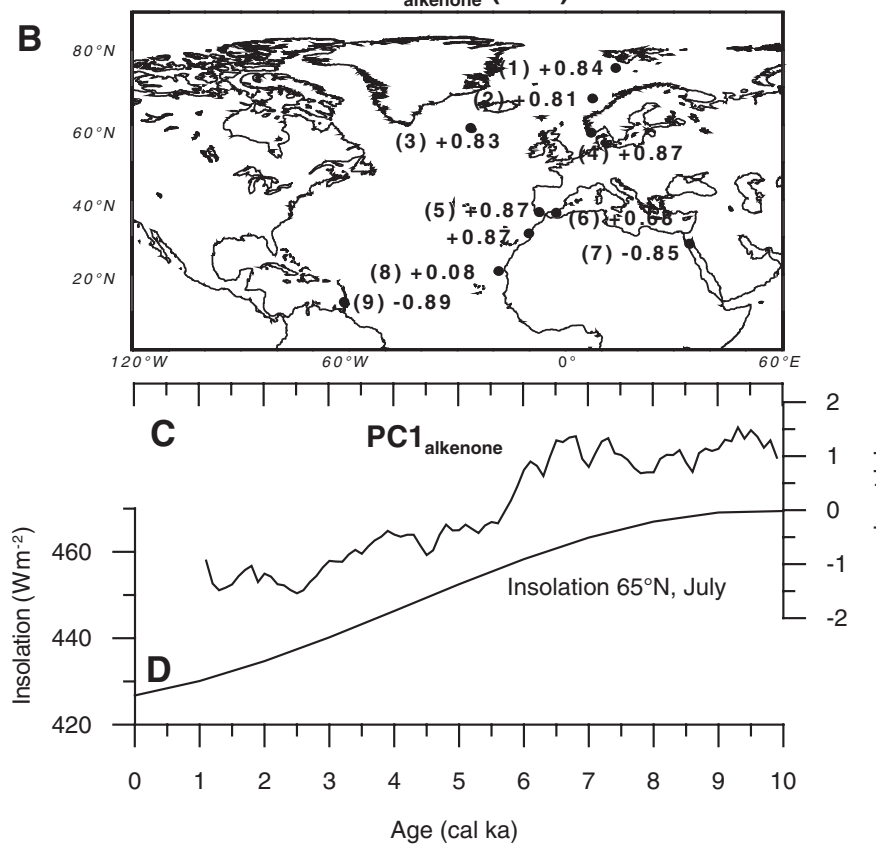

Figure 3. A: Alkenone-derived sea-surface temperature (SST) estimates used for empirical orthogonal function (EOF) analysis (Table DR2; see footnote 1). ODP-Ocean Drilling Program. B: First EOF none SST variability, which describes $62 \%$ of alkenone SST variance. C: Associated time coefficients $\left(\mathrm{PC}_{\text {alkenone }}\right)$. Values from $\mathrm{EOF}_{\text {alkenone }}$ map in $\mathrm{B}$ are correlation coefficients between $\mathrm{PC} 1_{\text {alkenone }}$ and normalized alkenone SST field. Numbers in parentheses in $B$ correspond to cores in A. D: Insolation changes at $65^{\circ} \mathrm{N}$ for July induced by Earth's orbital parameters (Berger and Loutre, 1991).

positive AO-NAO phases was the consequence of a more sensitive response to the North Atlantic subtropical gyre circulation than to the strengthened upwelling intensity. Given that temperature and salinity has a positive relation in the subtropical oceans (Wolff et al., 1999), stronger gyre circulation during the positive AO-NAO phases might also have increased salinities in the study area (Fig. DR1; see footnote 1). Consequently, increased salinities might have caused heavier $\delta^{18} \mathrm{O}_{G \text {. bulloides }}$ values, while warmer SSTs exercised competing influences on the $\delta^{18} \mathrm{O}_{G \text {. bulloides }}$ signal. The heavier $\delta^{18} \mathrm{O}_{G \text {. bulloides }}$ signals during the positive AO-NAO phases imply that the salinity effect on $\delta^{18} \mathrm{O}_{G \text {. bulloides }}$ might have overpowered SST effect. However, there is no sound evidence that the increased advection of saltier water mass via the gyre circulation outweighed simultaneously increased SSTs in controlling $\delta^{18} \mathrm{O}_{\text {G. bulloides }}$. Our study therefore highlights the needs of salinity reconstruction and $G$. bulloides abundance data for a better understanding of $\delta^{18} \mathrm{O}_{G \text {. bulloides }}$ signals (SST versus salinity and gyre circulation versus upwelling) and for changes in upwelling intensity off NW Africa.

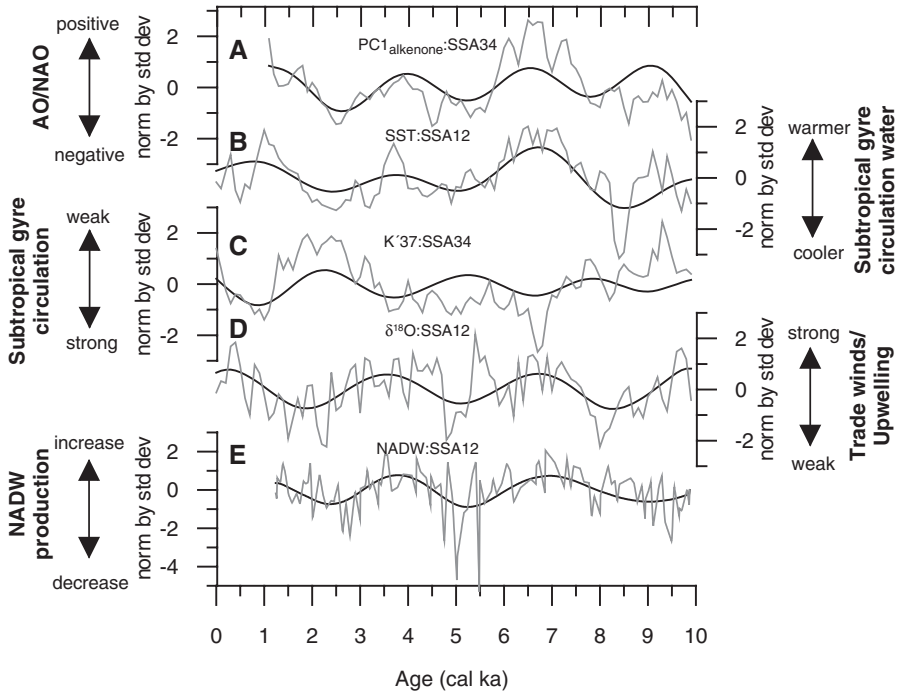

Figure 4. Reconstruction of time coefficients. A: $P C 1_{\text {alkenone }}\left(P C 1_{\text {alkenone }}\right.$ : SSA34, 27\%). SSA-singular spectrum analysis. B: GeoB 6007-2 alkenone sea-surface temperature (SST) (SST:SSA12, 36\%). C: GeoB 6007-2 alkenone concentration (K'37:SSA34, 23\%). D: GeoB 6007-2 $\delta^{18} \mathrm{O}_{\text {Globigerina bulloides }}\left(\delta^{18} \mathrm{O}: \mathrm{SSA} 12,27 \%\right)$. E: $\delta^{13} \mathrm{C}_{\text {cibicidoides wuellerstorfi }}$ (North Atlantic Deep Water (NADW) NADW:SSA12, 36\%) from third and

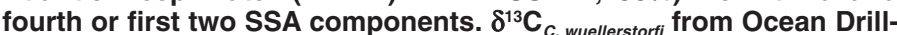
ing Program (ODP) Site $980\left(55^{\circ} \mathrm{N}, 15^{\circ} \mathrm{W} ; 2179 \mathrm{~m}\right.$ water depth, Oppo et al., 2003) records contribution of high $\delta^{13} C$ NADW relative to low $\delta^{13} \mathrm{C}$ Southern Ocean Water, and is used as proxy for past NADW production changes. All records shown as gray trace were detrended and normalized before SSA analysis, in order to capture millennialscale climate variations. AO-Arctic Oscillation. NAO-North Atlantic Oscillation.

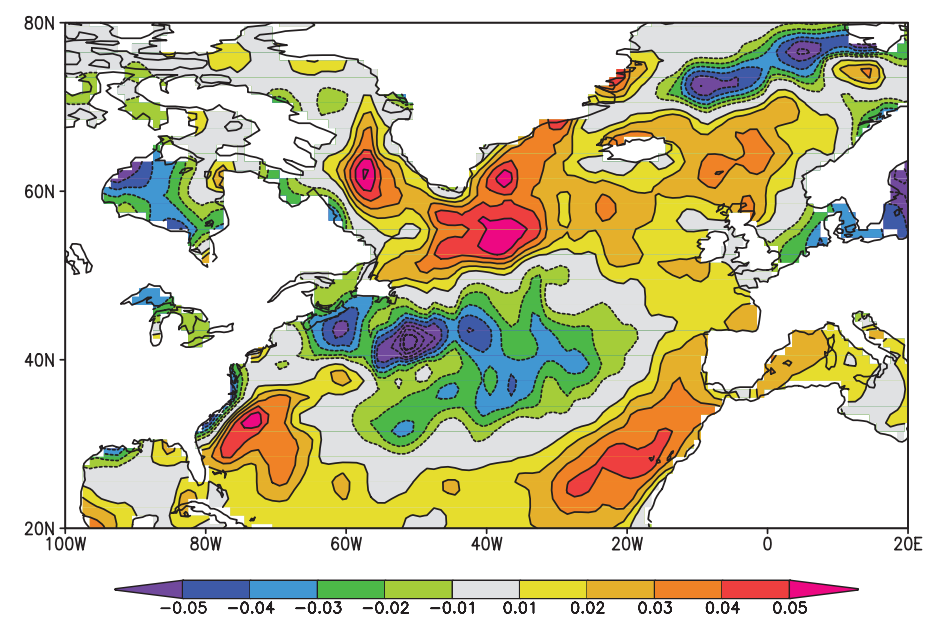

Figure 5. Regression of sea-surface temperature (SST) with Gulf Stream index. Units are ${ }^{\circ} \mathrm{C}$ per $1 \mathrm{~Sv}=10^{6} \mathrm{~m}^{3} / \mathrm{s}$. Monthly SSTs were provided by Reynolds et al. (2002) on $1^{\circ}$ grid. We also used data from oceanic current flowing northward along eastern coast of Florida carrying warm tropical waters that eventually feed Gulf Stream (Baringer and Larsen, 2001). Common time for SST and Florida Current is period 1982-2005.

\section{CONCLUSIONS}

Our well-dated Holocene high-resolution SST record off NW Africa shows a long-term cooling trend of $\sim 2{ }^{\circ} \mathrm{C}$ in the subtropical North Atlantic in response to boreal summer insolation. Superimposed on the cooling trend, we detect a pronounced cooling event of $\sim 1^{\circ} \mathrm{C}$ ca. $8.5 \mathrm{cal} \mathrm{ka}$ and a 2-3 k.y. cycle of climate variability. The cooling event coincides with a 
distinct and pronounced temperature drop associated with a slowdown of NADW formation related to the $8.2 \mathrm{ka}$ event. Our alkenone SST record off Cape Ghir provides the first evidence for the impact of this event on subtropical North Atlantic SSTs. Besides this shift, the 2-3 k.y. cycle is the most dominant and coherent periodicity of alkenone SST and upwelling intensity in the North Atlantic realm during the Holocene. The alkenone SST off NW Africa was more sensitive to the North Atlantic subtropical gyre circulation than to the upwelling intensity. This implies that the ocean circulation played a more significant role for 2-3 k.y. periodic variations than was previously thought. Future studies will elaborate the associated modes and spatio-temporal patterns of Holocene climate variability by using more high-resolution data and models.

\section{ACKNOWLEDGMENTS}

We thank the GHOST contributors for providing their alkenone data. We acknowledge constructive comments by H. McGregor, E.J. Rohling, T. Herbert, and four anonymous reviewers. This study was funded by grants from the German Ministry of Research and Education through the Global Holocene Spatial and Temporal Climate Variability program and the Marine, Coastal, and Polar Systems program, as well as from the German Research Foundation to the Research Center Ocean Margin, University Bremen.

\section{REFERENCES CITED}

Abrantes, F., Megers, H., Nave, S., Bollman, J., Palma, S., Sprenglel, C., Henderiks, J., Spies, A., Salgueiro, E., Moita, T., and Neuer, S., 2002, Fluxes of micro-organisms along a productivity gradient in the Canary Islands region $\left(29^{\circ} \mathrm{N}\right)$ : Implications for paleoreconstructions: Deep-Sea Research. Part II, Topical Studies in Oceanography, v. 49, p. 3599-3629, doi: 10.1016/S0967-0645(02)00100-5.

Barber, D.C., Dyke, A., Hillaire-Marcel, C., Jennings, A.E., Andrews, J.T., Kerwin, M.W., Bilodeau, G., McNeely, R., Southon, J., Morehead, M.D., and Gagnon, J.-M., 1999, Forcing of the cold event of 8,200 years ago by catastrophic drainage of Laurentide lakes: Nature, v. 400, p. 344-348, doi: $10.1038 / 22504$.

Baringer, M.O., and Larsen, J.C., 2001, Sixteen years of Florida Current transport at 27N: Geophysical Research Letters, v. 28, p. 3179-3182.

Berger, A., and Loutre, M.F., 1991, Insolation values for the climate of the last 10 million years: Quaternary Science Reviews, v. 10, p. 297-317, doi: 10.1016/0277-3791(91)90033-Q.

Bond, G., Kromer, B., Beer, J., Muscheler, R., Evans, M.N., Showers, W., Hoffmann, S., Lotti-Bond, R., Hajdas, I., and Bonani, G., 2001, Persistent solar influence on North Atlantic climate during the Hocene: Science, v. 294, p. 2130-2136, doi: 10.1126/science.1065680.

Curry, R.G., and McCartney, M.S., 2001, Ocean gyre circulation changes associated with the North Atlantic Oscillation: Journal of Physical Oceanography, v. 31, p. 3374-3400, doi: 10.1175/1520-0485(2001)031<3374: OGCCAW>2.0.CO;2.

Dima, M., Felis, T., Lohmann, G., and Rimbu, N., 2005, Distinct modes of interdecadal variability in a climate reconstruction of the last centuries from a South Pacific coral: Climate Dynamics, v. 25, p. 329-336, doi: 10.1007/ s00382-005-0043-2.

Kroon, D., and Darling, K., 1995, Size and upwelling control of the stable isotope composition of Neogloboquadrina dutertrei (d'Orbigny), Globigerinoides ruber (d'Orbigny) and Globigerina bulloides d'Orbigny; examples from the Panama Basin and Arabian Sea: Journal of Foraminiferal Research, v. 25, p. 39-52.

Lawrence, K.T., Liu, Z., and Herbert, T.D., 2006, Evolution of the eastern tropical Pacific through Plio-Pleistocene glaciation: Science, v. 312, p. 79-83, doi: $10.1126 /$ science. 1120395 .

Lohmann, G., 2003, Atmospheric and oceanic freshwater transport during weak Atlantic overturning circulation: Tellus, v. 55 A, p. 438-449.

Lohmann, G., Rimbu, N., and Dima, M., 2004, Climate signature of solar irradiance variations: Analysis of long-term instrumental, historical, and proxy data: International Journal of Climatology, v. 24, p. 1045-1056, doi: $10.1002 /$ joc. 1054

Lohmann, G., Lorenz, S.J., and Prange, M., 2005, Northern high-latitude climate changes during the Holocene as simulated by circulation models, in Drange, H., et al., eds., The Nordic Seas: An integrated perspective: American Geophysical Union Geophysical Monograph 158, p. 273-288.

Lorenz, J.S., Kim, J.-H., Rimbu, N., Schneider, R.R., and Lohmann, G., 2006, Orbitally-driven insolation forcing on Holocene climate trends: Evidence from alkenone data and climate modelling: Paleoceanography, v. 21, p. PA1002, doi: 10.1029/2005PA001152.
Marchal, O., Cacho, I., Stocker, T.F., Grimalt, J.O., Calvo, E., Martrat, B., Shackleton, N., Vautravers, M., Cortijo, E., van Kreveld, S., Andersson, C., Koç, N., Chapman, M., Sbaffi, L., Duplessy, J.-C., Sarnthein, M., Turon, J.-L., Duprat, J., and Jansen, E., 2002, Apparent long-term cooling of the sea surface in the Northeast Atlantic and Mediterranean during the Holocene: Quaternary Science Reviews, v. 21, p. 455-483, doi: 10.1016/S0277-3791(01)00105-6.

Mayewski, P.A., Rohling, E.J., Stager, J.C., Karlén, W., Maasch, K.A., Meeker, L.D., Meyerson, E.A., Gasse, F., van Kreveld, S., Holmgren, K., Lee-Thorp, J., Rosqvist, G., Rack, F., Staubwasser, M., Schneider, R.R., and Steig, E.J., 2004, Holocene climate variability: Quaternary Research, v. 62, p. $243-$ 255, doi: 10.1016/j.yqres.2004.07.001.

Meincke, J., 2002, Climate dynamics of the North Atlantic and NW-Europe: An observation-based overview, in Wefer, G., et al., eds., Climate development and history of the North Atlantic realm: Berlin, Heidelberg, SpringerVerlag, p. 25-40.

Müller, P.J., and Fischer, G., 2001, A 4-year sediment trap record of alkenones from the filamentous upwelling region off Cape Blanc, NW Africa and a comparison with distributions in underlying sediments: Deep-Sea Research. Part I, Oceanographic Research Papers, v. 48, p. 1877-1903, doi: 10.1016/ S0967-0637(00)00109-6.

Müller, P.J., Kirst, G., Ruhland, G., von Storch, I., and Rosell-Melé, A., 1998, Calibration of the alkenone palaeotemperature index based on core-tops from the eastern South Atlantic and the global ocean $\left(60^{\circ} \mathrm{N}-60^{\circ} \mathrm{S}\right)$ : Geochimica et Cosmochimica Acta, v. 62, p. 1757-1772, doi: 10.1016/S00167037(98)00097-0.

Oppo, D.W., McManus, J.F., and Cullen, J.L., 2003, Deep water variability in the Holocene epoch: Nature, v. 422, p. 277-278, doi: 10.1038/422277b.

Prange, M., Lohmann, G., Romanova, V., and Butzin, M., 2004, Modelling tempo-spatial signatures of Heinrich Events: Influence of the climatic background state: Quaternary Science Reviews, v. 23, p. 521-527, doi: 10.1016/ j.quascirev.2003.11.004.

Renssen, H., Goosse, H., Fichefet, T., and Campin, J.-M., 2001, The 8.2 kyr BP event simulated by a global atmosphere-sea-ice-ocean model: Geophysical Research Letters, v. 28, p. 1567-1570, doi: 10.1029/2000GL012602.

Reynolds, R.W., Rayner, N.A., Smith, T.M., Stokes, D.C., and Wang, W., 2002, An improved in situ and satellite SST analysis for climate: Journal of Climate, v. 15, p. 1609-1625, doi: 10.1175/1520-0442(2002)015<1609: AIISAS $>2.0 . \mathrm{CO} ; 2$.

Rimbu, N., Lohmann, G., Kim, J.-H., Arz, H.W., and Schneider, R., 2003, Arctic/ North Atlantic Oscillation signature in Holocene sea surface temperature trends as obtained from alkenone data: Geophysical Research Letters, v. 30, p. 1280, doi: 10.1029/2002GL016570.

Rimbu, N., Lohmann, G., Lorenz, S.J., Kim, J.-H., and Schneider, R.R., 2004 Holocene climate variability as derived from alkenone sea surface temperature and coupled ocean-atmosphere model experiments: Climate Dynamics, v. 23 , p. $215-227$, doi: $10.1007 / \mathrm{s} 00382-004-0435-8$.

Rohling, E.J., and Pälike, H., 2005, Centennial-scale climate cooling with a sudden cold event around 8,200 years ago: Nature, v. 434, p. 975-979, doi: 10.1038/nature03421

Rohling, E.J., Mayewski, P.A., Abu-Zied, R.H., Casford, J.S.L., and Hayes, A., 2002, Holocene atmosphere-ocean interactions: Records from Greenland and the Aegean Sea: Climate Dynamics, v. 18, p. 587-593, doi: 10.1007/ s00382-001-0194-8.

Stramma, L., and Siedler, G., 1988, Seasonal changes in the North Atlantic subtropical gyre: Journal of Geophysical Research, v. 93, p. 8111-8118.

Stuiver, M., and Grootes, P.M., 2000, GISP2 oxygen isotope ratios: Quaternary Research, v. 53, p. 277-284, doi: 10.1006/qres.2000.2127.

Sutton, R.T., and Allen, M.R., 1997, Decadal predictability in Gulf Stream sea surface temperature: Nature, v. 388, p. 563-567, doi: 10.1038/41523.

von Grafenstein, U., Erlenkeuser, H., Müller, J., Jouzel, J., and Johnsen, S., 1998 The cold event 8200 years ago documented in oxygen isotope records of precipitation in Europe and Greenland: Climate Dynamics, v. 14, p. 73-81, doi: $10.1007 / \mathrm{s} 003820050210$.

Wolff, T., Grieger, B., Hale, W., Dürkoop, A., Mulitza, S., Pätzold, J., and Wefer, G., 1999, On the reconstruction of paleosalinities, in Fischer, G., and Wefer, G., eds., Use of proxies in paleoceanography: Examples from the South Atlantic: Berlin, Springer-Verlag, p. 207-228.

Zhao, M., Beveridge, N.A.S., Shackleton, N.J., Sarnthein, M., and Eglinton, G., 1995, Molecular stratigraphy of cores off northwest Africa: Sea surface temperature history over the last 80 ka: Paleoceanography, v. 10, p. 661675, doi: 10.1029/94PA03354.

Manuscript received 17 August 2006

Revised manuscript received 12 December 2006

Manuscript accepted 17 December 2006

Printed in USA 